\title{
Beckett, pedagogo do ator: práticas de esgotamento
}

Beckett and his actor's pedagogy: Exhaustion practices

\section{Tatiana Motta-Lima}

Tatiana Motta-Lima

Atriz, diretora de teatro e professora adjunta da Universidade Federal do Estado do Rio de Janeiro (UNIRIO).

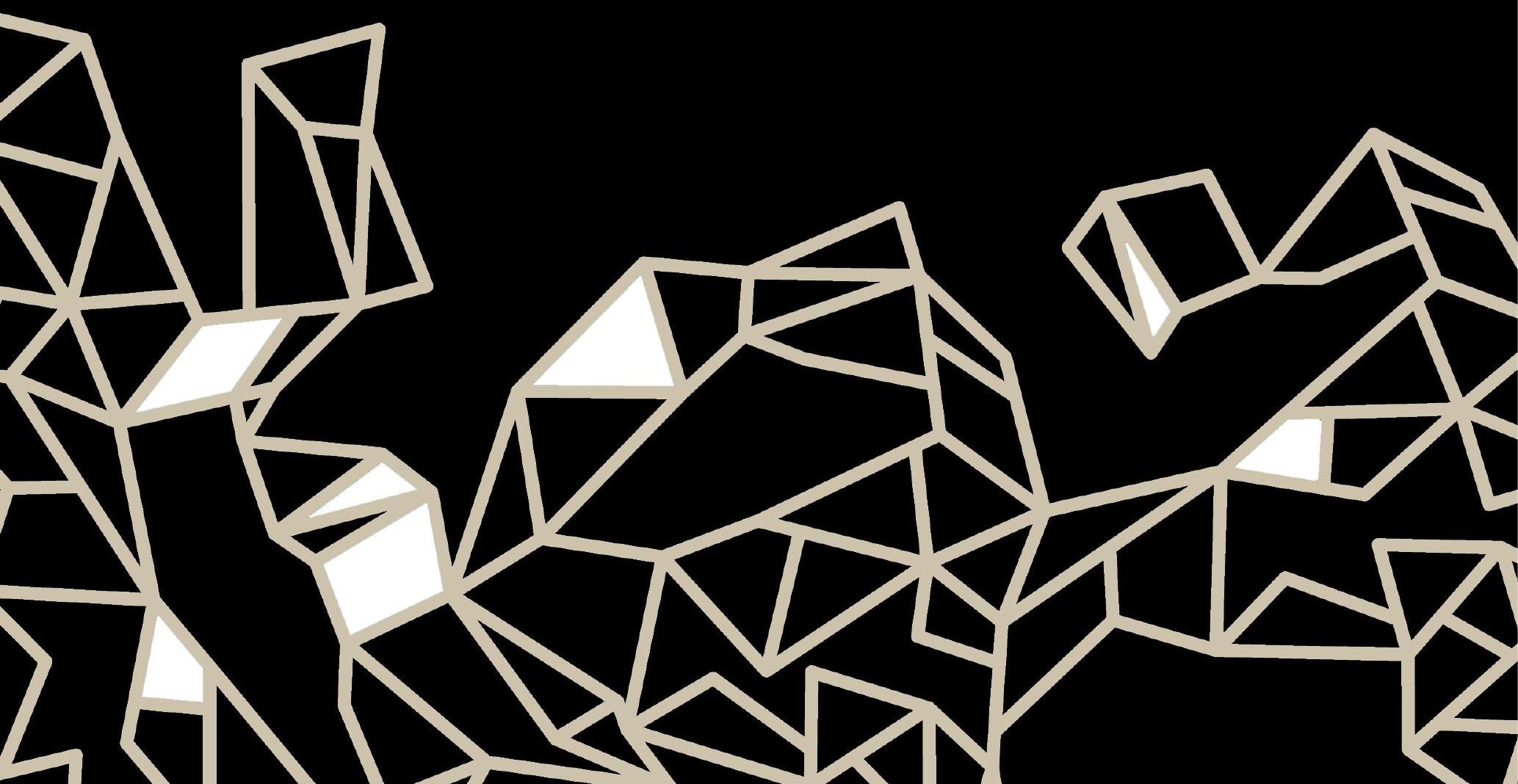




\section{Resumo}

Os textos de Samuel Beckett convidam o ator a descobrir lugares insuspeitados do ser. Eles podem ser vistos como mapas que indicam modos de ser/ fazer ou, dizendo de outra maneira, modos de subjetivação que "bagunçam" nossas ideias/práticas mais imediatas de indivíduo, sujeito, personalidade, e, portanto, de ator/atuação e de formação de atores. O que está em jogo são novas relações entre textualidade, oralidade, corporeidade e subjetivação. Nesse sentido, Beckett pode ser visto com um pedagogo (ainda que muito sui generis) do ator. Seus textos podem ser pensados como pedagógicos, já que ensinam/convocam a uma atuação "outra": múltipla, desmembrada, falhada, apagada, extremamente autoconsciente e que, ao mesmo tempo, acha "alegre ainda não ter estabelecido com o menor grau de precisão o que é." Uma das perguntas centrais dessa pedagogia beckettiana poderia ser: como formar o ator sem produzir uma reificação individualista? Como formá-lo promovendo - e/ou a partir de - novos modos de subjetivação?

Palavras-chaves: Beckett, Pedagogias do ator, Subjetividade, Modos de subjetivação, Corpo.

\section{Abstract}

Samuel Beckett's writings invite the actor to discover unsuspected places in himself. They can be seen as maps that indicate ways of being/doing or, in other words, modes of subjectivation that "mess up" our most immediate ideas/practices of individual, subject, personality, and therefore actor/ acting and training of actors. The issue involves new relations among textuality, orality, corporeality, and subjectivation. In this sense, Beckett can be seen as someone that developed an actor's pedagogy (even though very sui generis). His texts can be thought of as pedagogical, since they teach/ call upon "another" way of acting: multiple, dismembered, failed, erased, extremely self-conscious, and which, at the same time, finds it "joyful not to have established what it is with the least degree of accuracy". One of the central questions of this beckettian pedagogy could be: how to train the actor without producing an individualist reification? How to train him promoting - or starting from - new modes of subjectivation?

Keywords: Beckett, Actor pedagogies, Subjectivity, Modes of subjectivation, Body. 
Venho ministrando, há alguns anos, a oficina "quanto a mim vai ser alegre que não foi dado estabelecer com o menor grau de precisão o que sou" (BECKETT, 1989, p. 110), uma oficina baseada em determinados fragmentos de textos d'O Inominável de Beckett e do Livro do Desassossego de Pessoa. E agora, há bem pouco tempo, comecei o que chamamos de um experimento cênico,"hentre hos hanimais hestranhos heu hescolho hos humanos"1, que se debruça também sobre estes textos. O que me levou a estes fragmentos passa por uma miríade de memórias, afetos, pensamentos e também de perguntas. Creio que eles apontam para o ator, e para aqueles interessados na sua formação, uma problemática sobre modos de subjetivação e ainda oferecem determinado "artesanato", modos de fazer (ou de mal fazer, veremos isso mais à frente) que deixam pistas importantes para a atuação e para a pedagogia da atuação.

Neste texto, vou me concentrar mais em Beckett. Mas, tenho acreditado que a dobradinha Beckett-Pessoa permite vislumbrar diferentes linhas de fugas desse eu - indivíduo identitário - a que estamos submetidos. Não vou apresentar conclusões - não as tenho - mas o movimento ou o exercício do que vem sendo a minha investigação sobre esses textos/temas, principalmente no campo pedagógico, mas também no campo artístico estrito senso, se é que esses espaços possam ser separados.

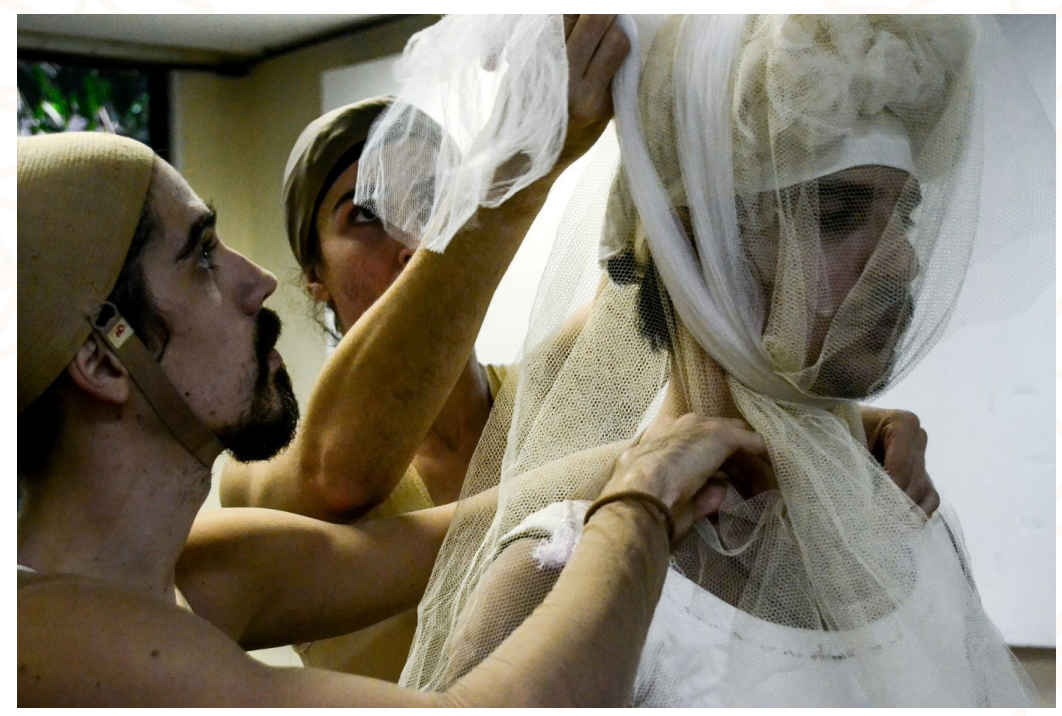

Figura 1 - Foto de Maria Duarte para o experimento cênico Hanimais hestranhos. Na foto: Leonardo Samarino, Jefferson Zelma e Matheus Gomes da Costa.

1 Poema visual de Arnaldo Antunes (2006, p. 67). 
Em Beckett e Pessoa, vejo a possibilidade de ler uma pedagogia outra para o ator, que pode ser utilizada para encenar um texto desses autores ou servir para outros textos/cenas. Assim, é necessário dizer que não vou falar de um estilo de atuação que permitiria interpretar os textos becktianos ou pessoanos. Vejo os textos de Beckett e Pessoa como pedagógicos porque colocam o ator cara a cara com o que me parecem ser questões centrais da atuação: quem é este 'eu' que atua? Com que 'eu' se atua? Para que 'eu' se atua? Ou, como atuar pode ser deparar-se com diferentes modos de subjetivação?

A pergunta feita por Grossman a partir dos textos de Beckett pode ser feita à maioria dos processos de criação atoral, ou, ao menos, àqueles que me interessam: "Qual sujeito sem figura se fará intérprete de uma figura sem sujeito?” (GROSSMAN, 2004, p. 80). Um 'sujeito sem figura', aquele que não foi cooptado inteiramente pelos processos de enunciação, de representação, aquele aonde ainda há espaço para o inominável, o irrepresentável, para o que não se quer ver. Uma 'figura sem sujeito', aquela que revela, já que puro artifício, a linguagem como mecanismo, como máquina de produzir indivíduos.

Um sujeito sem figura pode ser aquele que se percebe afeito ao que Cassiano Quilici nomeou de "A Experiência da Não Forma": afeito àquilo "que foge ao domínio das representações, que emerge nas lacunas e fissuras do simbólico, que flutua numa região de incertezas", e que "tende a ser ignorado e esquecido". A arte aparece como que sustentando "uma abertura para o que não cai nas malhas da representação," o que se desloca para fora das percepções "construídas e interpretadas segundo padrões habituais aprendidos e herdados" (QUILICI, 2015a, p. 120-121).

Acredito que a questão mais importante que devemos enfrentar na formação de atores - e alguns de nós a temos enfrentado - diga respeito a investigar com um olhar agudo o modo como temos experienciado, em sala de aula de atuação (e nos palcos), as noções de eu/pessoa/sujeito/indivíduo. Não adiantaria pensarmos/praticarmos novas linguagens, técnicas, repertórios corporais ou teóricos; não adiantaria opormos performance a teatro (ou performer a ator), narrativas lineares a narrativas fragmentadas, ficcional a biográfico se essas investigações não estivessem vinculadas à percepção 
e à criação de modos de subjetivação que passam, necessariamente, pelo corpo do ator.

Pode haver - se isso nos interessa - uma relação entre uma formação em uma dada prática artística e um modo singular de constituir a própria existência e é sobre isso que venho me interrogando. Na verdade, creio que há sempre uma relação entre artesanato, técnica e produção de subjetividade, mesmo que não queiramos ver. Nossos modos de fazer partem de determinados modos de compreender o que é o sujeito (o que somos) e, ao mesmo tempo, acabam por construí-lo.

A questão é que se não nos debruçamos sobre essa relação entre modos de fazer (o artesanato) e modos de subjetivação, corremos o risco de reproduzirmos, com os mais diferentes dispositivos, e com as melhores intenções, subjetividades assujeitadas. O eu-indivíduo acaba por comer, recortar e nomear experiências díspares a partir de um mesmo ponto de vista, produzindo uma enunciação identitária para aquilo que poderia ter potencial de construção de diferença e devir.

Como diz Pelbart, no seu texto Biopolítica (2007), no biopoder, o poder teria tomado de assalto a vida. Ele incidiria sobre nossas maneiras de perceber, sentir, amar, pensar, criar. A normatização, aqui, não é vista como um poder externo ao sujeito. Ao contrário, ela nos compõe (e recompõe permanentemente), nos organiza.

Quando se fala, então, em formação de artistas como processo de criação de si, deve-se perceber que esse processo só pode se dar como um processo de resistência ao biopoder, resistência que passa pela crítica e pela autocrítica, por algum modo de interrupção, ao que parece, em uma primeira instância, nos construir/constituir. Tal processo se dá também pela criação de dobras e linhas de fuga (construção de estratégias) em relação àquele que em mim quer interpretar, nomear, estacionar aquilo que é, por sua própria constituição, dinamismo e diferença.

Um exemplo: o trabalho do ator sobre sua memória individual pode tanto andar na direção de uma reificação do indivíduo, do sujeito, como servir de ponte para um 'fora' ou um 'neutro' (no sentido dado por Blanchot), servir de ponte para algo que seria impessoal. $E$ isso vai depender de como pensamos e praticamos a subjetividade. Optaremos por uma memória que nos narra - e 
que nos faz sempre idênticos a nós mesmos, ou, o que parece muito mais interessante, nos abriremos para uma memória que nos chama - que chama aquilo que é outro em nós? ${ }^{2}$

Peter Brook disse, em 1962, que o que era burguês, classe média, e continuava sendo no teatro, era a "maneira de considerar os homens" (BROOK, 1983 , p. 3). Creio que quando se trata de formação de atores - mesmo no século XXI - não estamos tão longe dessa afirmação, porque é justamente no ator (a partir dele, sobre ele, em agenciamento com ele) que estaria em jogo a exploração de outros modos de subjetivação ou, se quisermos, também de dessubjetivação. E essa exploração não tem sido, parece-me, o principal foco de nossas preocupações no chamado teatro "pós-dramático", mesmo - ou, talvez, sobretudo - no que diz respeito a uma insistência na diferença entre ação e representação. ${ }^{3}$

Assim, o convite feito neste texto é aquele de pensar uma experiência de formação teatral que primeiro: ultrapasse uma formação em seu sentido instrumental, e isso sem desconsiderar a importância do artesanato, pois é na relação com o dispositivo, e não fora dele, em qualquer abstração do pensamento, que se constrói o lócus de uma possível percepção outra de si, que pode dar-se um outrar-se (eu outro, tu outras, ele outra...). Segundo: pensar a formação de ator para fora de uma reificação individualista.

Como abordar o ator, como formá-lo sem essa reificação? O individualismo - este modo de fazer sujeito - coloca para o ator, como sabemos, uma série de problemas, recortando-os - e mesmo cegando-os - para as relações e os devires, fazendo-os insistir em ser um centro (o centro) a partir do qual objetos, colegas, materiais, espectadores circulam - o que em outro texto chamei de ator-imã (MOTTA-LIMA, 2009) - , incitando-os mais à comunicação (que produz signos) que à experiência dos processos vitais.

Então, que relação com o corpo, com a voz, com os vivos e os não-vivos - outros, objetos, materiais -, com a enunciação, para que se coloque em questão a presença autoritária de um sujeito representacional sobre um corpo? Como o corpo abre mão de ser - ou ser apenas - espaço de representação de

2 Escrevi, para esta mesma revista Sala Preta, o artigo intitulado "Experimentar a Memória ou Experimentar-se na Memória" que aprofunda essas questões.

3 Recomendo, para melhor analisar essas noções e desnaturalizá-las: Qulici, 2015², p. 107-116. 
um indivíduo? Que novo regime de visibilidade, que olhar de professor sustentaria, suportaria e mesmo demandaria esse "inominável"? E, se o sujeito-ator não é o indivíduo, como então? Ou, parafraseando Beckett: "quem, agora?" (BECKETT, 1989, p. 5)

A resposta, se bem entendemos a força do biopoder, não pode ser respondida apenas ao se propor um novo modo de fazer, um novo método. Não há exercícios e modelos que funcionem para todos e todas, a todo o tempo, pois os modos de subjetivação assujeitada que nos estruturam, que estruturam alunos e alunas, professoras e professores, estão sempre prontos a se apropriar de qualquer técnica ou método. Mas, se a resposta não está em um modo de fazer, “Onde, agora? Quando, agora?" (BECKETT, 1989, p. 5). Talvez ela esteja em um determinado modo de perguntar e na força que temos para suportar e manter estas(s) pergunta(s). Talvez esteja na coragem de abrir mão, largar, abandonar o já sabido e aprendido (e, assim, de certa maneira, abandonar-se, abandonar aquilo que nos narra - nos constitui - como indivíduos e atores já (re)conhecidos).

Nesse sentido, Beckett, no seu Inominável é quase modelar. Vou abordá-lo (e a seu texto) como se fosse um pedagogo para o ator, aquele que anunciei no título deste artigo. Um Beckett criador, talvez, de um antimétodo ou, ainda mais importante do que isso, um perguntador valente e incansável das perguntas que podem fazer sentido na formação de atores.

Ele age como alguém que recorda aos pedagogos de atores e aos próprios atores sobre o que se debruçar para não cair nas citadas do modelo individualizante de pessoa. Beckett não é um modelo de ação pedagógica, não explica o que deve ser feito, mas pode ser um modelo para a ação pedagógica, que coloca perguntas, provoca desestabilizações, ou desfaz aquelas certezas que pareciam, à primeira vista, mais úteis e potentes. Transpor estas perguntas - espécie de quedas no abismo - para o campo da formação de ator, inventar esse Beckett pedagogo - e não creio que ele gostaria minimamente deste título - tem sido a minha brincadeira favorita.

Beckett - e seu Inominável - mostra-nos todo o tempo como a linguagem - sua linearidade, dicotomia, sua mania de construir narrativas em torno de causas e consequências, sua necessidade de tudo explicar e possuir, de tudo localizar, de aglutinar em enunciações conhecidas experiências 
díspares e sem nome, podem encarcerar o sujeito. Seu projeto é fazê-la, a linguagem, cair no descrédito:

Como nós não podemos eliminar a linguagem subitamente, nós deveríamos ao menos fazer todo o possível a fim de contribuir para sua queda no descrédito. Cavar um buraco após o outro nela, até que o que se espreita atrás dela - seja isso alguma coisa ou nada - comece a vazar através. Eu não posso imaginar um objetivo superior para um escritor hoje. (BECKETT apud CAVALCANTI, 2006, p. 21)

Estamos encarcerados no corpo da mesma maneira que estamos encarcerados na língua? Parece-me que sim. O corpo - seus apetites e sensações - acaba, em certa medida, por se transformar em linguagem, ser aprisionado nas nomeações. Assim, para seguir com Beckett e desacreditar a linguagem, é preciso desacreditar (ou ao menos desconfiar) da narrativa, nomeável e identitária daquele que fala, identidade muitas vezes espelhada no corpo do falante.

Segundo Fábio de Souza Andrade: "O único caminho possível para chegar a esse discurso depurado é uma via negativa, que passa pela demonstração de tudo aquilo que ele [personagem, ator] não é, da insuficiência mentirosa dos múltiplos aspectos que ele já assumiu no passado" (ANDRADE, 2001, p. 147). Para Grotowski, a formação do ator também deve se dar em uma via negativa: menos aquisição hábil de aparatos de construção do que queda daquilo que bloqueia o fluxo da vida em uma dada estrutura - seja exercício, cena, improvisação, encontro, etc. Grotowski diz: "não um estado pelo qual 'queremos fazer aquilo', mas 'desistimos de não fazê-lo'” (GROTOWSKI, 1986, p. 15). O ator da via negativa é campo de uma possível atualização dos fluxos, da vida: perderia o nome, barraria a enunciação, renunciaria à expressão pela curiosidade do que passa através.

Outra imagem potente para compreender o trabalho de Beckett e que também se une à vida negativa - e à famosa exaustão grotowskiana - é a imagem do Esgotado de Deleuze. Diferente do cansado que esgota a realização (estou cansado e não posso fazer - subjetivamente -, uma coisa que pode ser feita - objetivamente), o Esgotado esgota o possível (e, para Deleuze, o possível são os objetivos, os projetos, as preferências, as disjunções exclusivas - ou quente ou frio - , as significações, as necessidades). 
Deleuze se pergunta: ele esgotaria o possível porque está esgotado ou estaria esgotado porque esgotou o possível? Ele se esgotaria ao esgotar o possível e inversamente. O que estaria em jogo aqui, no esgotamento do possível, é um esgotamento do eu construído exatamente a partir e através desse possível. O esgotado de Beckett e o exaurido de Grotowski são, de certa maneira, primos. Ao esgotarem-se, expõem um corpo/eu agido pela linguagem e pelo intelecto, agido pelo poder, ao mesmo tempo em que vislumbram outros modos de subjetivação, outros corpos.

$\mathrm{E}$, nesse "fim de mim", há, tanto para Beckett quanto para Grotowski, uma "falta que promete". A citação é de Malone Morre: "Minha história terminada, ainda vou estar vivendo. Falta que promete. É o fim de mim. Não vou mais dizer eu" (BECKETT, 1986, p. 137).

Mas, poderia também citar Grotowski: "Se se pede ao ator para fazer o impossível e ele o faz, não é ele-o ator que foi capaz de fazê-lo, porque ele-o ator pode fazer somente aquilo que é possível, que é conhecido. É o seu homem que o faz" (GROTOWSKI, 2007, p. 176). Aqui, a promessa se concretiza no percepção/surgimento de uma alteridade.

Deleuze diz que muitos autores se contentam em proclamar a morte do “eu.' Mas, que Beckett vai além: mostra como o 'eu' se decompõe, incluindo o mau cheiro e a agonia (DELEUZE, 2010, p. 72). O psicanalista Marcus Quintaes reconhece o trabalho analítico como algo semelhante. Em uma palestra, citou James Hillman dizendo que o processo analítico era "menos uma superação e um livrar-se do que uma decadência, uma decomposição do modo como estamos compostos. Os alquimistas chamaram a isso "putrefactio", (HILLMAN, 2008).

Vamos, então, ao que chamei de putrefactio becketiano, recolhido não com o intuito de explicar Beckett, ou o Inominável, mas de recolher pistas, nos textos de Beckett, para vislumbrar, a partir delas, uma possível pedagogia para o ator. Textos de Pessoa também aparecerão aqui e ali.

Para facilitar a apresentação, transformei essas pistas em seis tópicos aos quais dei títulos (creio que ainda existem muitos outros tópicos, mas minha investigação está começando...).

Então, 


\section{Putrefactio 1: Chega desta puta primeira pessoa}

É justamente isso que diz Beckett em O Inominável. Vejamos: "Logo chega desta puta primeira pessoa, é demais por fim, não se trata dela, vou me causar aborrecimentos. Mas, não se trata também de Mahood, ainda não. De Worn, menos ainda. Bah, pouco importa o pronome desde que não nos deixemos enganar por ele" (BECKETT, 1989, p. 61).

Beckett convidaria - lendo-o como este pedagogo inventado - o ator a não se enganar pelos pronomes, seja o 'eu' do ator/performer, seja o 'ele' da personagem ficcional. É na instabilidade, ou no alargamento, ou na abertura ou no abandono temporário do(s) pronome(s) que o que é inominável, desconhecido, pode aparecer, que a criação pode se dar.

Fábio de Souza Andrade disse que: "o inominável [...] é ele próprio uma rede de palavras, um prisioneiro do presente da enunciação relativizado pela instabilidade da própria identidade" (ANDRADE, 2001, p. 165). O que me interessa aqui é esse processo possível de relativização: o que poderia relativizar a enunciação, que procura permanentemente forjar causas e efeitos decorrentes, escrever narrativas lineares, é justamente a instabilidade da identidade. Quando o eu não reconhece suas palavras e/ou não se reconhece nas suas palavras, ou as vê como possibilidade de construção ficcional, justamente por essa não identificação, ele abre um espaço de liberdade, um vazio, um gap.

Andrade cita ainda Robert Champagni quando este diz que O Inominável é: "Um monólogo menos conduzido que assombrado pela primeira pessoa, percorrido pelo pronome convertido em variante expandida do ponto de interrogação" (CHAMPAGNI apud ANDRADE, 2001, p. 150). Em O Inominável, a primeira pessoa é verdadeiramente uma assombração, ela está lá como um fantasma ao qual não se acredita demasiadamente. Ela é mais um ponto de interrogação do que um ponto final. A primeira pessoa aceita sua instabilidade, aceita ser reconduzida a uma pergunta (eu, quem?) - lugar de onde não deveria ter saído. Além disso, há um cansaço, um esgotamento (a manutenção de uma identidade é exigente/cansativa para o ser e sua 'natureza' fluida e instável). Está-se, então, disponível a abandonar esta pesada ficção - o que é o mesmo que experimentar abandonar-se (SAFATLE, 2016). 
Uma boa pista para o ator: distanciar-se e desconfiar das respostas habituais, mecânicas, padronizadas, talvez aquelas às quais ele tenha mais apego. A atenção, liberta do trabalho de tudo reunir sob o nome 'eu', pode correr por outras veredas, abrir-se justamente para o que não é 'eu', uma atenção flutuante, uma escuta não objetivante, um olhar/boca/estômago que não quer tudo deglutir imediatamente.

Sobre a questão da liberdade, Beckett dizia em sua primeira peça, Eleutheria:

Sempre quis ser livre. Não sei por quê. Não sei também o que isso significa, ser livre. Mesmo que me arrancassem todas as unhas não saberia dizê-lo. Porém, longe das palavras, sei o que é isso. Eu sempre desejei isso. E ainda o desejo. É só o que desejo. Primeiro era prisioneiro dos outros. Então, abandonei-os. Logo, tornei-me prisioneiro de mim mesmo. Foi pior. Então, me abandonei. (BECKETT apud MARFUZ, 2014, p. 13)

Tenho experimentado a imagem de que o ator é palco para a cena e não personagem dela. Palco, por exemplo, para as sensações, entendidas, num viés deleuziano, como "o produto não subjetivo, não interiorizado, de relação de forças que constituem (e deformam) as formas" (GARCIA, 2012, p. 130). Palco para a vida, palco para os trecos - objetos, roupas - e, palco para o próprio sujeito. As figuras que aparecem em cena são o palco dos acontecimentos, o humano é pensado como instalação.

Dizer "chega desta puta primeira pessoa", no trabalho do ator, pode ser também abrir-se a outras potências, não humanas. Peter Brook, ao se deparar com um determinado tipo de literatura, onde personagens eram 'forças', teve que fazer apelo às máscaras para que os atores pudessem fazer um salto para fora do 'homem' (BROOK, 1994, p. 282-305). Não estar, como diz Beckett, só "crrac, entre os vivos", ou entre os homens, mas poder outrar-se, inclusive para fora do antropocentrismo: "Acreditam eles que eu acredito que sou eu quem fala? Isso também é deles. Para me fazer acreditar que tenho um eu meu e que posso falar dele, como eles do seu. É ainda uma armadilha, para que eu me veja de repente, crrac, entre os vivos" (BECKETT, 1989, p. 64) 


\section{Putrefactio 2: Não estar muito presente}

"Quando a atriz Billie Whitelaw pergunta a Beckett, em pleno ensaio, se a personagem Mother, de Passos, está viva ou morta, ele responde: Digamos que você não está muito presente" (MARFUZ, 2014, p. 53).

Nosso pedagogo nos dá aí uma segunda pista. Educar o ator para que ele não esteja muito presente, educá-lo também para ausência. Um ator ausentado. A corporeidade não aponta para a presença de um sujeito-personagem-ator, mas para a decomposição desta tríade. $O$ ator pode ser vértice para a presença de uma força dessubjetivante.

Grossman, falando sobre Beckett, diz que ele produz uma "língua em um movimento incessante de desfiguração. [...] se traindo, se apagando e renascendo, inventando incansavelmente um ritmo que impede o sentido de tomar forma, de se fixar em forma, em figura (GROSSMAN, 2004, p. 52). A pergunta que nasceria para a pedagogia atoral, e que me interessa, seria: como pesquisar/inventar com o ator esse mesmo ritmo que impede a identificação entendida como estabilização das formas?

Talvez experimentar alguma paragem. Fazer amizade com o silêncio, com o vazio, com o não saber, com um determinado tipo de esquecimento, possa ajudar. Ou, por outro lado, uma atenção que possa seguir - velozmente - os contatos, afirmar os caminhos do fluxo orgânico, do corpo-canal. Do mesmo jeito, trabalhar na percepção dos detalhes, dos cacos - cacos de gestos, cacos de coisas, cacos de sensações - pode ser de valia para que não se esteja muito ali.

Gosto de pensar neste ator como quem está aprendendo seu ofício a partir deste trecho de Fernando Pessoa: "Desenrolo-me como uma meada multicolor, ou faço comigo figuras de cordel, como as que se tecem nas mãos espetadas e se passam de umas crianças para as outras. Cuido só que o polegar não falhe o laço que lhe compete. Depois viro a mão e a imagem fica diferente. E recomeço" (PESSOA, 2006).

Ou aprendendo com Willie, de Dias Felizes, a testemunhar uma determinada opacidade: "Sensação estranha. (pausa. ação). Sensação estranha de que alguém me olha. Eu fico nítida, depois flú, depois desaparece, depois 
novamente flú, depois novamente nítida, e assim por diante, indo e vindo, passado e voltando, no olho de alguém" (BECKETT, 2002, p. 15).

\section{Putrefactio 3: Fazer mal, dizer mal, ver mal.}

Assim como ele é, ator, assim como ele se conhece e se nomeia, ele faz (ou quer fazer) as coisas bem (integralmente, de maneira coesa, sem vazios ou gaps, evitando a todo custo a instabilidade e a diferença). E, para isso, ele convoca seu intelecto a controlar seus processos (antes mesmo de conhecê-los), a disciplinar seu corpo/voz - Grotowski diria, de maneira crítica, a adestrar, a marionetar seu corpo/voz - controlando os impulsos vitais e os processos de deriva.

Fazer mal, dizer mal e ver mal. Escolhi nomear assim esse segundo putrefactio, para afirmar que o ator necessitaria perceber/criar novos regimes de sensibilidade, de visibilidade, de oralidade. É preciso mal ver o já visto (e, às vezes, mesmo fechar os olhos), para poder ver diferente. Mal dizer (e mesmo maldizer) aquilo que aparece como já dito - e mesmo bendito por todo um regime da oralidade atoral - para poder ensaiar dizer o não dito (lembrar aqui das críticas de Novarina e de sua "Carta aos Atores"). É preciso agir longe do princípio de causalidade e enunciação - um corpo produtor de signos a serem lidos - para ser agido pela vida que corre no corpo, para encontrar um corpo, como dizia Grotowski, da (e para a) organicidade ${ }^{4}$ (MOTTA-LIMA, 2012).

Há, nesse putrefactio 3 , um necessário movimento de resistência e de escape àquilo que bloqueia o fluxo da vida. E escapar pode ser, em um primeiro momento, suspender, colocar em dúvida, estranhar o já sabido. Grossman se pergunta: "Como não fixar em um quadro aquilo que o olho vê? Ver mal (Artaud dizia: ver de soslaio). Como não fixar em texto o que o sujeito diz? Dizer mal. Como melhor mal ver? Fechar os olhos.' Poderíamos continuar com Grossman e dizer que "mal ver" é também não fixar um único ponto de vista. Ela ainda se pergunta: "Como melhor mal dizer?" Não estabelecer um lugar (um 'eu') estável de enunciação. E como melhor mal escutar? Como um psicanalista, uma escuta flutuante (GROSSMAN, 2004, p. 76-79).

4 Trabalhei de forma bastante exaustiva sobre o conceito/prática da organicidade nos marcos 3 e 4 do meu livro (2012, p. 164-290). 
Leminski (1986, p. 145-157), no posfácio à Malone Morre, mostra como Beckett escrevia com um "emprego quase intoxicante de "modificadores", do tipo "talvez," "quem sabe", "de certa maneira", "visto de um certo ângulo," "se não me engano". É como se nada se fechasse de uma vez por todas. Há um processo de tensão com o já estabelecido, com as formas corretas de fazer.

Como criar estes mesmos tipos de "modificadores" na formação e criação atoral? E também na condução do formador de atores?

\section{Putrefactio 4: Fracassar}

Beckett disse: "eu trabalho com a impotência, a ignorância [...]. Minha exploração é essa zona falhada do ser que tem sido posta de lado pelos artistas como coisa inútil - como coisa, por definição, incompatível com a arte" (BECKETT apud CAVALCANTI, 2006, p. 20). Como construir uma pedagogia de ator que explore justamente as zonas falhadas, os fracassos de encaixe na máquina-mundo e na máquina-teatro?

Grossman diz: "Fracassar é um processo sem fim (em Beckett, não acabamos nunca de acabar), movimento daquele que, constantemente, trai a propensão da escrita a tomar forma, da imagem a se fixar" (GROSSMAN, 2004, p. 78).

Leminski mostra este processo quando nota que além daqueles índices de indeterminação, há aqueles que ele chama de "anuladores", e que fazem com que frase, ideia e sujeito da enunciação fracassem: "Muitas vezes, Beckett conduz aquela longa frase, cheia de reentrâncias, golfos e baías, para concluir dizendo: "ou não é nada disso", ou "o que seria impossível," ou "que bom se fosse verdade", bombas frasais de efeito retroativo, que destroem a validade da frase que se acaba de anunciar" (LEMINSKI, 1986, p. 156).

Tenho pensado este fracasso como um desamparo, seguindo certas ideias de Safatle que vê a arte como força de despossessão do sujeito, como acontecimento capaz de nos abrir para afetos que nos desamparem da nossa condição de indivíduo: "Estar desamparado é deixar-se abrir a um afeto que me despossui dos predicados que me identificam. Por isso, é um afeto que me confronta com uma impotência que é, na verdade, forma de expressão do 
desabamento de potências [fracassos, portanto] que produzem sempre os mesmos atos, sempre os mesmos agentes" (SAFATLE, 2016, p. 21).

Como professores, creio que não podemos ter medo de lidar com o desamparo (ou a angústia) que podem surgir nestes processos, já que ele pode ser o disparador de processos de diferenciação. Aqui, Safatle também nos ajuda quando afirma em uma conferência ministrada na UFRJ em 11 de abril de 2016: "Há uma experiência de emancipação vinculada à afirmação do desamparo, mas ela não pode ser pensada em moldes tradicionais como uma experiência de autonomia”. Não produzir a autonomia de um dito sujeito, mas uma emancipação, pelo desamparo.

Como vimos, na via negativa, toda nossa força que rejeita a organicidade, por exemplo, fazendo outra coisa, que resiste se ocupando da construção identitária, fracassa. Algo - um desbloqueio de outras forças e formas - se faz nesse, e justamente por causa desse, fracasso.

\section{Putrefactio 5: Mania de comparecer aos próprios des- encontros 5}

Em Beckett, o despedaçamento da figura vai de par com uma

intensa narração de relatos autobiográficos que, entretanto, problematizam a coerência, a estabilidade e a homogeneidade do sujeito falante. São relatos em que elas falam de si para si mesmas e que, em vez de servirem ao seu autoconhecimento, vêm justamente colocá-lo em xeque. Ao narrar a sua própria história, a personagem fala de 'si mesma' como se fosse de um outro, testemunhando o desmoronamento (pela linguagem) de uma sua suposta unidade, fixidez, imutabilidade e permanência. (CAVALCANTI, 2006, p. 56)

O "pedagogo" Beckett oferece aqui algumas imagens ao professor de atores: fala da importância de experimentar ganhar uma distância dentro daquilo que se faz, de poder produzir, enquanto se age, um testemunho da própria ação. Brook falava da relação do ator com seu personagem - mas podemos desdobrar esse pensamento para uma relação do ator consigo mesmo - como da relação entre a mão e a luva. Um comprometimento que não perde

5 Essa frase foi retirada do Poema “A Disfunção”, de Manoel de Barros (2001). 
um espaço de ar, a luva, embora adquira o formato da mão, não está grudada nela, não é a mão - que permite, dando continuidade à metáfora, um espaço de testemunho, que lida com o vazio "entre".

Como experimentar com o ator estes desencontros, esse testemunho? Isso diz respeito a todo um trabalho sobre a atenção, a percepção ao momento presente. Talvez possamos brincar de perceber o ver, o pensar, o falar, o ouvir-se falar, o agir, o movimentar a boca não mais como partes de uma única operação realizada por um sujeito unívoco e coerente, mas como pedaços testemunháveis - e objetiváveis - daquilo a que damos o nome de "eu". E talvez essa experiência da sensação construa a experiência de uma impessoalidade, como, muitas vezes, assinalou Fernando Pessoa. Lembro-me particularmente do poema "Apontamentos", onde os "cacos absurdamente conscientes [...] conscientes de si mesmos" ofereceriam ao narrador maiores sensações do que àquelas que tinha "quando me sentia eu" (PESSOA, 2010).

Quando a sensação de uma inteireza surge, ela não é um apossar-se de algo, ela não nasce da expressão de um sujeito, mas é como uma canalização mais sutil ou aguda de inúmeros vetores (ou forças, ou entidades, como queiramos chamar). E, neste sentido, inteireza seria o oposto de identidade. Estar inteiro seria dar vazão, seria ausentar-se, seria trabalhar modos de vacância. Deixar que a vida corra ou escorra ou escoe por você. Mas do que buscar algo que te pertença, é você que oferece a algo a tua pertença. Você se faz vacância para dar vazão. Você caça - no sentido de não resistir, de desistir de não fazer - momentos de vida fugidios (não para tê-los, mas para a eles pertencer).

Safatle fala, inclusive, que o vínculo social/político se daria exatamente nesse inassimilável. Nós nos encontraríamos/reconheceríamos naquilo que em todos é provisório, precário, instável. E esta pode ser uma boa dica para pensarmos a relação deste trabalho de ator, que aqui interessa, com o seu espectador. Mas, é um ponto para tratarmos em outro momento.

\section{Putrefactio 6: Rir (do/de si)}

Rir é também uma maneira de tomar distância do 'eu'. Rir de si pode ser rir do próprio si. Afastar-se. 'Olhar mal' o sofrimento, 'ouvir mal' as súplicas e 
choros. Não fazer sujeito no sofrer. Uma espécie de dor sem sofrimento. Uma imagem do Inominável pode nos auxiliar aqui: Beckett fala em lágrimas que escorrem sem cessar no rosto da personagem. Embora ela possa descrever a sensação, estas lágrimas escorrem sem causa ou consequência determinadas. Como algo que chora ou quer chorar. E não como um eu que chora porque algo Ihe ocorreu. Um choro impessoal que podia nascer de um riso. $O$ riso pode instaurar também momentos de uma lucidez mais relacionada com o corpo, diferentemente do cinismo e da ironia nos quais o mental tem, parece-me, trabalho preponderante. No riso, tomar distância não é apartar-se do corpo, mas vivenciá-lo de outra maneira. Não levar-se tão a sério. Rir de si, para rir do si. E esta espécie de riso está permanentemente presente em O Inominável. O riso que nasce também da constatação - em detalhes e não genérica ou abstrata - de nossa condição desamparada.

Enfim...

Para acabar, é preciso lembrar que este aqui é um exercício no qual a filosofia, a teoria, fornece os meios de construção de um campo semântico que torna possível pensar modos de subjetivação múltiplos, para além da reificação individualista, na formação do ator. Estes termos impactam sobre a representação do sujeito como indivíduo e propõem outros modos de pensar criação atoral, formação do ator e, também a conduta do professor/formador. Contudo, o indivíduo não é apenas, ainda que isso não seja pouco, um modo de se conceber. Ele também é um modo de sentir, agir, sofrer, amar. Assim, o ator (e o professor) pode se encher de palavras filosóficas e ser constantemente recapturado pela definição individualista de sujeito. É no trabalho artístico, no trabalho sobre o ator, que se estabelece esse campo de batalha entre o sujeito indívíduo e a produção de um corpo prenhe de virtualidades. É ali que se interdita, se combate, por meio da máquina crítica e sensível da via negativa, por meio do humor, por meio do fracasso, do esgotamento e da interrupção, as artimanhas do sujeito indivíduo.

Há por fim, no Inominável um desejo por silenciar, um desejo de silêncio, desejo que nunca se presentifica. Este desejo é como uma seta no caminho da dessubjetivação. Para falar dele, encontrei um texto de Kafka com o qual gostaria de finalizar este texto. Chama-se Desejo de se Tornar Índio. E, se a tradução fosse de um deleuziano, talvez pudesse chamar-se "devir-índio": 
Se realmente se fosse um índio, desde logo alerta e, em cima do cavalo na corrida, enviesado no ar, se estremecesse sempre por um átimo sobre o chão trepidante, até que se largou as esporas, pois não havia esporas, até que se jogou fora as rédeas, e diante de si mal se viu o campo como pradaria ceifada rente, já sem pescoço de cavalo nem cabeça de cavalo (Kafka, 1991, p. 47).

The And. ${ }^{6} \mathrm{Ou}$, "é preciso continuar, não posso continuar, vou continuar."7

\section{Referências bibliográficas}

ANDRADE, F. S. Samuel Beckett: o silêncio possível. São Paulo: Ateliê, 2001.

ANTUNES, A. Como é que chama o nome disso: Antologia. São Paulo: Publifolha, 2006.

BARROS, M. Tratado geral das grandezas do ínfimo. Rio de Janeiro: Record, 2001. BECKETT, S. Dias felizes. Tradução Bárbara Heliodora. Rio de Janeiro: Banco de Peças Teatrais, Biblioteca da UNIRIO, 2002.

Malone morre. Tradução Paulo Leminski. São Paulo: Brasiliense, 1986.

O Inominável. Tradução Waltensir Dutra. Rio de Janeiro: Nova Fronteira, 1989.

BROOK, P. A máscara: saindo de nossas conchas. In: O ponto de mudan-

ça: 40 anos de experiências teatrais: 1946-1987. Rio de Janeiro: Civilização Brasileira, 1994. p. 267-305.

.Em busca de uma fome. Cadernos de Teatro, n. 96, p. 1-8, jan./mar. 1983.

CAVALCANTI, I. Eu que não estou aí onde estou: o teatro de Samuel Beckett. Rio de Janeiro: 7 letras, 2006.

DELEUZE, G. Sobre o teatro: um manifesto de menos: o esgotado. Tradução Fátima Saadi, Ovídio de Abreu e Roberto Machado. Rio de Janeiro: Jorge Zahar, 2010.

GARCIA, G. C. Dizer o Indizível: histeria e heteronímia. Revista Poiésis, v. 19, p. 119-135, jun. 2012.

GROSSMAN, E. La defiguration: Artaud, Beckett, Michaux. Paris: Minuit, 2004.

GROTOWSKI. J. Em busca de um teatro pobre. Rio de Janeiro: Civilização Brasileira, 1986.

O Teatro Laboratório de Jerzy Grotowski: 1959-1969. São Paulo: Perspectiva; Fondazione Pontedera Teatro, 2007.

HILLMAN, J. A grande mãe, seu filho, seu herói e o Puer. In: O livro do Puer: ensaios sobre o arquétipo do Puer Aeternus. Tradução Gustavo Barcellos. São Paulo: Paulus, 2008. p. 65-116.

6 Poema Visual de Arnaldo Antunes, 2006, p. 154.

7 Texto final de "O Inominável” de Beckett (1989). 
KAFKA, F. Contemplação/O Foguista. São Paulo: Companhia das Letras, 1999.

LEMINSKI, P. Beckett, o apocalipse e depois. In: BECKETT, S. Malone Morre. Tradução Paulo Leminski. São Paulo: Brasiliense, 1986.

MARFUZ, L. Beckett e a implosão da cena: poética teatral e estratégias de encenação. São Paulo: Perspectiva, 2014.

MOTTA-LIMA, T. Atenção, porosidade e vetorização: por onde anda o ator contemporâneo? Revista Subtexto, n. 6, p. 27-36, dez. 2009.

Experimentar a memória ou experimentar-se na memória: apontamentos sobre a noção de memória no percurso artístico de Jerzy Grotowski. Sala Preta, v. 9, p. 159-170, 2009. Disponível em: <http://dx.doi.org/10.11606/issn.2238-3867. v9i0p159-170>. Acesso em: 6 dez. 2016.

Palavras Praticadas: o percurso artístico de Jerzy Grotowski (1959-1974). São Paulo: Perspectiva, 2012.

PELBART, P. P. Biopolítica. Sala Preta, v. 7, p. 57-66, 2007. Disponível em: <http://dx. doi.org/10.11606/issn.2238-3867.v7i0p57-66>. Acesso em: 6 dez. 2016.

PESSOA, F. Livro do Desassossego. São Paulo: Companhia das Letras, 2006.

Poemas de Álvaro de Campos: Obra Poética IV. Porto Alegre: LP\&M, 2010.

QUILICI, C. A experiência da não forma. In: O Ator-performer e as poéticas da transformação de si. São Paulo: Annablume, 2015a. p. 117-123.

Ação e Representação nas Artes Performativas. In: O Ator-performer e as poéticas da transformação de si. São Paulo: Annablume, 2015b. p. 107-116.

SAFATLE, V. O circuito dos afetos: corpos políticos, desamparo e o fim do indivíduo. Belo Horizonte: Autêntica, 2016.

Recebido em 17/10/2016 Aprovado em 28/10/2016 Publicado em 21/12/2016 